\title{
FERTILITY AND FINANCIAL DEVELOPMENT: EVIDENCE FROM U.S. COUNTIES IN THE 19TH CENTURY
}

\author{
Alberto Basso \\ Howard Bodenhorn \\ David Cuberes \\ Working Paper 20491 \\ http://www.nber.org/papers/w20491
NATIONAL BUREAU OF ECONOMIC RESEARCH
1050 Massachusetts Avenue
Cambridge, MA 02138 \\ September 2014
}

We thank Antonio Navas, Bastien Chabe-Ferret and seminar participants at the 2013 Warwick Summer School in Economic Growth, at the 2014 RES conference in Manchester and at the 2014 ESPE conference in Braga for their useful comments. The views expressed herein are those of the authors and do not necessarily reflect the views of the National Bureau of Economic Research.

NBER working papers are circulated for discussion and comment purposes. They have not been peerreviewed or been subject to the review by the NBER Board of Directors that accompanies official NBER publications.

(C) 2014 by Alberto Basso, Howard Bodenhorn, and David Cuberes. All rights reserved. Short sections of text, not to exceed two paragraphs, may be quoted without explicit permission provided that full credit, including $\odot$ notice, is given to the source. 
Fertility and Financial Development: Evidence from U.S. Counties in the 19th Century Alberto Basso, Howard Bodenhorn, and David Cuberes

NBER Working Paper No. 20491

September 2014

JEL No. N21,N31,N91,R2

\begin{abstract}
$\underline{\text { ABSTRACT }}$
The old-age security hypothesis establishes that one important reason why parents have a large offspring is to ensure that they will receive financial support from them in old age. In this paper we use data on fertility and financial development in 19th century U.S. to indirectly test this theory. In particular, we explore whether more developed local financial markets reduce the incentives for families to have a large offspring. After controlling for several factors likely to create cross-county variation in fertility levels and for potential spatial correlation, we find that the presence of a bank and the degree of financial development in a given county are strongly associated with lower children-to-women ratios. We find compelling evidence for the old-age security hypothesis.
\end{abstract}

Alberto Basso

Plymouth Business School

Cookworthy Building, Drake Circus

Plymouth, PL4 8AA, UK

alberto.basso@plymouth.ac.uk

Howard Bodenhorn

John E. Walker Department of Economics

College of Business and Behavioral Science

201-B Sirrine Hall

Clemson University

Clemson, SC 29634

and NBER

bodenhorn@gmail.com
David Cuberes

Department of Economics

University of Sheffield

9 Mappin St

Sheffield S1 4DT

United Kingdom

d.cuberes@sheffield.ac.uk 


\section{Introduction}

In many modern developing countries and in rich countries around the time of their industrial revolution parents often viewed their children as an instrument to secure support when in old age. This is known as the old-age security hypothesis and it was first proposed by Neher (1971) and Caldwell (1976). This hypothesis suggests that in the absence of capital markets, children serve as an asset that permits parents to transfer income to old age. A direct implication is that the fertility levels in a given economic area (country, region, state, county) should be negatively associated with the development of its financial system.

The main purpose of this paper is to test the old-age security hypothesis using countylevel data in Northeastern United States around 1850. This is a sensible choice of country and time period to carry out this exercise since in the 19th century the U.S. experienced a rapid development in its financial and banking systems (see Bodenhorn and Cuberes 2010). ${ }^{1}$ Another important characteristic of this historical process of financial development is that there was a substantial heterogeneity across states and counties in granting bank charters (Bodenhorn 2008). ${ }^{2}$ Additionally, in the U.S. social insurance and pension systems were developed only after 1850: before the Social Security Act of 1935, there was no general social insurance system (Guinnane 2011). ${ }^{3}$ States did provide various types of poor relief, often to widows, orphans and the elderly, but the generosity of relief is believed to have declined between the 1810s and 1850s (Hannon 1984). The elderly could not rely on the state to support them in their old age.

In this paper we take advantage of the heterogeneity in fertility rates and bank charters across US counties to test the association between financial development and fertility choice around

\footnotetext{
${ }^{1}$ Sylla (1998) describes in detail the "Federalist financial revolution" that fundamentally changed the banking structure in the U.S. in the late 18th and early 19th century.

${ }^{2}$ For instance, in 1837 Massachusetts had 116 operating banks, while the figures for New York and Pennsylvania were 49 and 98 , respectively.

${ }^{3}$ Pension and health care systems are other substitutes for the provision of support during old age.
} 
1850. Our focus is on eight Northeastern states: Connecticut, Delaware, Massachusetts, New Hampshire, New Jersey, New York, Pennsylvania and Vermont.

We measure financial development using alternative measures that capture the presence of banks and the intensity of banking in each county around 1840-1850. Fertility levels are measured using mainly the child-woman ratio in 1850. We also consider Pennsylvania as a case study. This state has the advantage that Pennsylvania banking policy was slow to respond to changes in demand for banks. Because it is less likely that the effect of local banks on fertility reflects reverse causality in Pennsylvania, we take existing banks around 1850 as exogenous and we investigate their association with fertility in 1850 within the state.

We find a robust negative correlation between financial development and fertility, which strongly supporting the old-age security hypothesis. We do not argue that the old-age security motive is the main - nor even the most important - factor shaping fertility in historical U.S. Our results are rather interpreted as highlighting the importance of financial development as a mechanism reducing parents' incentives to have a large number of offspring. Our analysis indicates that the old-age security motive is economically important: OLS estimates suggest that the presence of a bank in a given county around 1850 reduces the child-woman ratio by approximately 3 percentage points, from 0.67 to 0.64 children per woman, or nearly onefourth of the standard deviation in fertility.

\section{Literature review}

The literature analyzing fertility behaviour points out several important factors that can explain differences in fertility by studying historical data (Guinnane 2011, Galor 2012). Among these, the most relevant ones are the demand for human capital and the corresponding inter-

play between quantity and quality of children (Galor and Weil, 2000), income (Becker and 
Lewis, 1973; Becker, 1981), child and infant mortality rates (Coale 1973; Sah 1991; Ehrlich and Lui 1991; Kalemli-Ozcan 2002; Tamura 2006), and different dimensions of gender gaps (Galor and Weil 1996; Goldin 1990; Lagerlöf, 2003).

There is an abundant literature in demography and economics that studies the direction of intergenerational family transfers, their motives, and how they are affected by different institutional and cultural arrangements. This literature argues that intergenerational transfers have a significant impact on family size, in particular desired fertility.

Several authors explore the old-age security hypothesis and its role in shaping the fertility behaviour from a theoretical perspective. Caldwell $(1976,1982)$ proposes a theory based on the idea that transfers from children to parents are the main reason behind parents' choice of having a large offspring. ${ }^{4}$ Nugent (1985) also emphasizes the importance of this channel (p.76): "old-age security is likely to be an important motive for fertility when the relevant parent is both uncertain about his or her ability to be self-supporting in old age and dubious that there are other more reliable or more effective means of such support than his or her own children." Ehrlich and Liu (1991) develop a dynamic overlapping-generation model of endogenous growth where different generations are interdependent through financial transfers. Morand (1999) presents a model in which growth and fertility interact with each other as a result of the fact that parents rely on their children to support them in old age. Boldrin and Jones (2002) also modify Barro and Becker (1989) to allow for altruism running from children to parents.

Financial development can affect fertility behaviour by reducing the importance of the oldage security motive. In fact it might be that (Guinnane 2011, p. 598) "children were an important way to ensure against risk and to provide for old age, and that the rise of state social insurance as well as private insurance and savings vehicles led households to substitute

\footnotetext{
${ }^{4}$ Willis (1980) formalizes Caldwell's argument in a highly stylized model.
} 
out of children". Under this hypothesis the spread of banks offers alternative means to provide for old age security. Financial development can affect fertility through the possibility of borrowing resources from banks, which renders current consumption less dependent on current income. If children were sent to work to provide additional resources to the household, the development of a banking system would then reduce parents' optimal number of children because the child's importance in providing contemporaneous income decreases. ${ }^{5}$

In spite of the solid theoretical foundation of the old-age security motive, the existing empirical evidence of its relevance is mixed. ${ }^{6}$ According to Galor (2012), while the old-age security hypothesis is one of the mechanisms that can explain differences in fertility levels, the existing evidence indicates that its role as trigger of a country's fertility transition is rather small. For instance, there is evidence that 16th century England had institutions that afforded parents financial assistance independent of their children (Pelling and Smith, 1991; Hindle, 2004) but fertility rates did not decline until several centuries later. ${ }^{7}$ Moreover, Galor argues that, before the demographic transition, richer households - who arguably had better access to financial services - tended to have higher fertility rates than poor ones, which also casts doubts on the old-age support hypothesis (Clark and Hamilton 2006). ${ }^{8}$ Brown and Guinnane (2002) use data for Bavaria in the period 1880-1910 to argue that the old-age security motive was in fact unimportant in that historical context. Finally, Kaplan (1994) using modern data from Peru and Paraguay finds evidence of intergenerational transfers from parents to children rather than the reverse, suggesting that the old-age support hypothesis

\footnotetext{
${ }^{5}$ Financial development can affect fertility also through the interaction with the business cycle. For example, during recessions a better access to banks can allow to relax the household budget constraint, thus potentially allowing families to have more children.

${ }^{6}$ Some authors have also criticized the old-age security hypothesis on theoretical grounds. See Nerlove, Razin and Sadka $(1986,1987)$.

${ }^{7}$ These institutions were known as English Poor Laws, a poor relief system introduced at the end of the 16 th century.

${ }^{8}$ The latter argument is however weak if it is indeed the case that most of the wealth of the rich relies on non-wage income since, in that case, there could exist an old-age security motive but fertility may be higher for rich households than for poor ones due to a pure income effect.
} 
is not operative in these countries.

On the other hand, other studies have found strong support for this hypothesis. Galloway et al. (1994) claim that this theory was relevant in Prussia between 1875 and 1910. In a study closely linked to ours Steckel (1991) also finds a negative correlation between financial development at the state level and fertility for a sample of rural families from across the U.S. in the 19th century. However, there are important differences between his study and ours. First, we use county-level data on financial development and fertility for the entire population, not just the rural population. Second, we enlarge the set of controls and attempt to deal with potential endogeneity problems. Finally, evidence in favour of the old-age hypothesis from several developing countries is provided by Nugent and Gillapsy (1983). Cain (1981) and Dharmalingam (1994) show this effect in India and Cain $(1977,1981)$ and Jensen (1990) in Bangladesh and Malaysia, respectively. ${ }^{9}$ Finally, Kagitcibasi (1982) and Willis (1980) find support for the old-age security hypothesis in a sample of countries emphasizing the importance of cultural aspects whereas Entwisle and Winegarden (1984) and Nugent and Gillapsy (1983) show that public policies targeted at old-age support have a negative effect on fertility.

\section{Theoretical benchmark}

In this section we develop a simple theoretical framework that rationalizes the negative relationship between financial development and the number of children a household chooses to have. This is meant to illustrate the main mechanism in place without developing a fullfledged model. Assume a household is formed by two parents and a number of children. Following Ray (1998), let $\alpha$ be the probability that a child looks after her parents when she grows up. This probability takes into account infant and child mortality, the possibility that

\footnotetext{
${ }^{9}$ Robinson (1986) argues that the old-age security does not really apply to Bangladesh.
} 
the child survives to adulthood but earns an income insufficient to provide for her parents, and the probability that her income is sufficient but she chooses not to look after them. Parents have access to a "technology" through which they can receive some income when old, namely the use of financial services provided by a local bank. One natural way to achieve this is to save when young and then use these savings and their financial return when old. ${ }^{10}$ Let $\beta$ be the probability that the location where the parents reside has a bank. ${ }^{11}$ Finally, let $\gamma$ be the threshold probability that of receiving some kind of economic support from at least a child or a bank that parents find acceptable. For instance, $\gamma=0.95$ means that parents find it intolerable to have more than a $5 \%$ chance that they would not receive any support from either a child or a bank when they get old.

We next assume that a household has $n$ children. Then the probability that none of them looks after their parents when they are old is $(1-\alpha)^{n}$. On the other hand, the probability that there is no local bank in which the household can make its savings grow is $1-\beta$. Therefore, the probability that parents will have some financial resources from at least a child or a bank is:

$$
1-\left[(1-\alpha)^{n}(1-\beta)\right]
$$

Parents want to guarantee that this probability is not lower than $\gamma$, which leads them to have at least $n^{*}$ children i.e.: ${ }^{12}$

\footnotetext{
${ }^{10}$ The importance of local banks in providing financial services to households has been explored, for instance, in Guiso et al. (2004).

${ }^{11}$ We use the term "location" here in a vague way so that it can refer to a town, city, or even a county. The important thing in our reasoning is that the bank is located "nearby" where households live so that it is reasonably easy - in the context of 19th century U.S - for them to visit this bank and use its financial services.

${ }^{12}$ We assume $\gamma>\beta$ to ensure a non-negative optimal number of children. This appears a realistic assumption since it seems reasonable that parents in 19th century U.S. had a markedly high aversion to reach old-age without financial support. For example, Ray (1998) suggests a value of $\gamma$ equal to 0.95. A plausible estimate of $\beta$ can be obtained from the percentage of counties with a bank aroun 1850 , which is $70 \%$ in our dataset, implying a value of $\beta$ of around 0.7
} 


$$
n \geq n^{*} \equiv \frac{\ln \left(\frac{1-\gamma}{1-\beta}\right)}{\ln (1-\alpha)}
$$

It is then easy to show that an exogenous increase in the probability that a bank is present near the household location - a proxy for financial development - reduces the number of children that this household chooses to have:

$$
\frac{\partial n^{*}}{\partial \beta}=\frac{1}{(1-\beta) \ln (1-\alpha)}<0
$$

\section{Data}

Our analysis exploits cross-county variation in order to assess the role of financial development on fertility choice. Our largest sample consists of 196 counties in the Northeastern United States (Connecticut, Delaware, Massachusetts, New Hampshire, New Jersey, New York, Pennsylvania, Rhode Island, and Vermont). Data on banks creation at the city-level is taken from Weber (2011) ${ }^{13}$ His dataset documents all banks in the United States prior to 1861. We aggregate Weber's data - available at the town level - to get county-level measures of financial development. Our first measure of financial development is the availability of banking, which we proxy with a dummy variable (labelled Bank dummy 1840s) taking on value one if there is some financial activity in the county over the period 1846-49. The second index we use is a measure of banking intensity (labelled Intensive banking 1840s) and it is calculated as the sum of a bank's circulating currency and deposits in per capita terms over the period 1846-49. ${ }^{14}$ We focus on currency and deposits because in the period we investigate the average person did not have a bank account and her most common way of saving

\footnotetext{
${ }^{13}$ This is available at http://www.minneapolisfed.org/research/economists/wewproj.cfm\#balancesheets.

${ }^{14}$ We apply a $\log$ transformation to this variable (i.e. $\log (1+\mathrm{x})$ ) to reduce the impact of outliers, also in light of the fact that for many counties this variable takes on a value of zero.
} 
was by holding bank-issued money or banknotes. These cash holdings are best captured in the data by the amount of circulating currency. ${ }^{15}$ While banknotes represented the most common form of money holdings, one motivation for which is precautionary savings, the use of deposits was increasing in the $1850 \mathrm{~s}$ in parts of the Northeast. Thus, we use the sum of currency and deposits as the relevant measure of local finance.

In order to assess the association between financial development and fertility, we are interested in measuring the "quantity" of children that a household has. Following recent papers (Becker et al. 2010, 2012) analyzing fertility-related issues in similar historical contexts, we measure fertility with the child-woman ratio computed as the number of children aged 0-4 relative to the number of women aged 15-39. ${ }^{16}$ As a robustness check we also use alternative definitions of the child-woman ratio, that is using children aged 1-4 (child-woman ratio 2) or 5-14 (childwoman ratio 3) and the crude birth rate. ${ }^{17}$ By using children aged 1-4 or 5-14, we remove the potential effect of infant or child mortality, thus capturing the effects of surviving children. All measures of fertility are calculated using the U.S. Population Census of 1850. As Figure 1 shows, there is a strong positive unconditional correlation (0.69) between the child-woman ratio and the crude birth rate across the counties in our sample.

We control for several factors considered important in determining fertility levels. To account for the role of human capital and the interplay between quantity and quality of children, we add as a regressor the school attendance rate in each county. This is measured as the number of individuals (white population) attending school over the population aged 5-19. One important variable that may determine fertility is income per capita. According to Becker (1981), if one makes the plausible assumption that the income effect on the demand

\footnotetext{
${ }^{15}$ Temin (1969) estimates that specie represented as little as 5 percent of the money supply in the early 1830s, though the fraction rose later in the antebellum era to around one-fifth.

${ }^{16}$ We restrict ourselves to the white population due to data availability, following other studies. However, from the U.S. census we know that the percentage of free colored and slaves in the states and time period that we analyze was very small, around $1.9 \%$.

${ }^{17}$ The crude birth rate is computed using surviving births until June 1, 1850, so it partially accounts for the effect of mortality during childhood, a variable considered important in explaining fertility choices.
} 


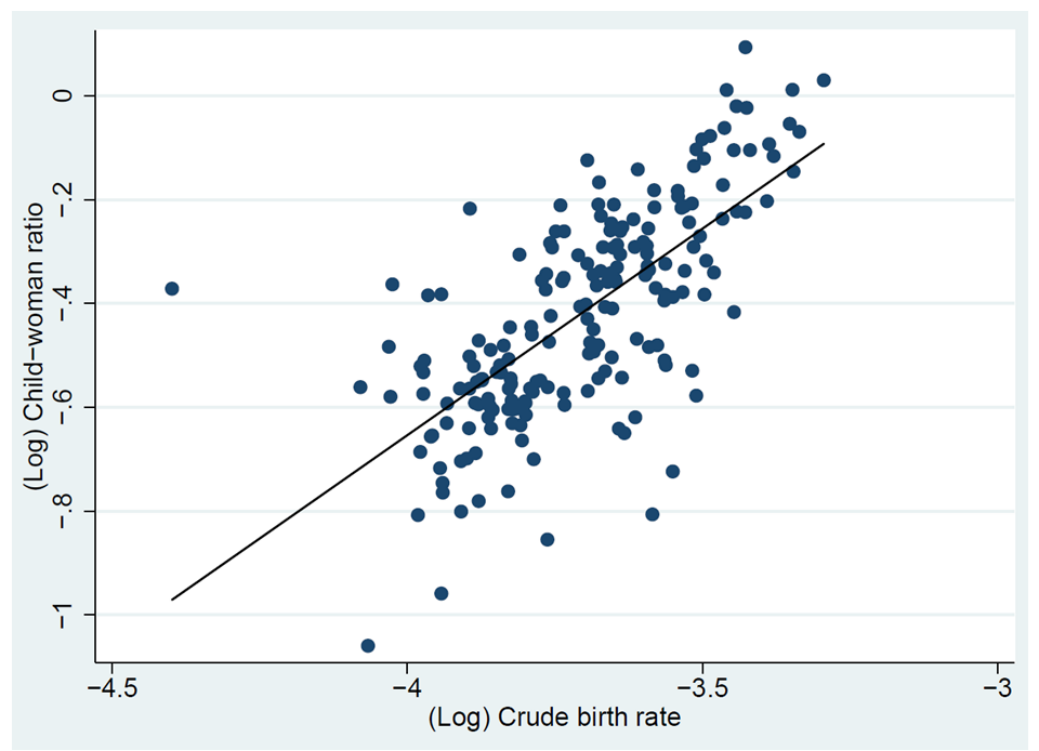

Figure 1: (Log) Child-woman ratio and (log) crude birth rate across counties

for children is smaller than the substitution effect households optimally choose to have fewer and more educated children when their income becomes sufficiently high. Because we do not have data on income per capita at the county level, we use two proxies. The first proxy is (per capita) public spending in schools that is financed through taxation: the rationale for this is that counties with higher income should also have larger revenues from taxation and hence more funds allocated to education. ${ }^{18}$ Our second proxy for income per capita is the county's urbanization's rate, defined as the share of population living in cities with at least 5,000 inhabitants. Apart from capturing the level of development and structure of a given county, the urban environment might be important because certain norms and cultural attitudes towards fertility - for example about contraception - tended to spread first in urban areas than in rural ones. Moreover, some authors have shown that fertility has historically been higher in rural areas than in urban ones (e.g. Galloway et al. 1998). ${ }^{19}$ As recent findings in the

\footnotetext{
${ }^{18}$ This measure also captures the supply of (public) education, which may be relevant for the child quantityquality trade-off discussed above.

${ }^{19}$ One may argue that per capita public spending in schools and urbanization are highly correlated and so including both variables as regressors may create problems of collinearity. However, in our case the correlation between the two variables is rather low, 0.26 .
} 
literature suggest (e.g. Bodenhorn and Cuberes 2013), urbanization in 19th century U.S. was largely influenced by financial development so by controlling for urbanization we capture the effect of banking on fertility independently of its effect on urbanization. Moreover, because of this positive correlation between two of our regressors the total effect of financial development on fertility levels is likely to be larger than the one captured by the estimate of our banking measure. We also control for the share of individuals employed in the manufacturing sector (in the population older than 15), as industrialisation might have increased opportunity cost of having children especially for women. Finally, we also account for agricultural productivity - measured as the value of farming implements/machinery per acre of improved land in farms because it is likely to affect income and, among other things, the demand for child labour. ${ }^{20}$

In our regressions we also introduce as controls several variables that, while they have not been pivotal in the existing theoretical models of fertility, we believe are relevant to explain cross-county variation in fertility levels in 19th century U.S. First, we include a measure of parents' education since - especially in the case of mother's education - it has often been regarded as an important factor in explaining fertility behaviour as it affects knowledge of fertility controls, earnings and preferences (e.g. Cochrane 1979; Becker et al. 2013). We measure parents' education with the percentage of literate white men and women older than 20 years of age. In order to address the importance of the economic and social role of women we also use the ratio between literate women and literate men, as a proxy for the wellestablished gender gap in education. Second, since marriage is one of the main explanatory factors of fertility behaviour, we use a proxy for married women computed as the number of families over women older than 15. Third, an important issue we account for is selective migration as it is possible that individuals who prefer finance to children as means of securing financial support at old age or that for some reason have few or no children may relocate closer

\footnotetext{
${ }^{20}$ For instance, Rosenzweig and Evenson (1977) show that agricultural productivity is positively related to child labour-force participation in rural India.
} 
Table 1: Variables and data sources

$\begin{array}{ll}\text { Child-woman ratio(s) } & \text { Authors' calculations using population census data } \\ \text { Crude birth rate } & \text { Authors' calculations using population census data } \\ \text { Bank dummy } & \text { Authors' calculations using Weber (2011) } \\ \text { http://www.minneapolisfed.org/research/economists/wewproj.html. } & \text { Authors' calculations using Weber (2011) } \\ \text { Intensive banking } & \text { http://www.minneapolisfed.org/research/economists/wewproj.html. } \\ \text { Share of literate women } & \text { Authors' calculations using population census data } \\ \text { Share of literate men } & \text { Authors' calculations using population census data } \\ \text { Education gap (women/men) } & \text { Authors' calculations using population census data } \\ \text { School attendance } & \text { Authors' calculations using population census data } \\ \text { Proxy income per capita } & \text { Authors' calculations using population census data } \\ \text { Share in manufacturing } & \text { Authors' calculations using population census data } \\ \text { Share of urban population } & \text { Authors' calculations using population census data } \\ \text { Share of married women } & \text { Authors' calculations using population census data } \\ \text { Marriage rate } & \text { Authors' calculations using population census data } \\ \text { Crude death rate } & \text { Authors' calculations using population census data } \\ \text { Agricultural productivity } & \text { Authors' calculations using population census data } \\ \text { Migration from other state } & \text { Authors' calculations using population census data } \\ \text { Migration from abroad } & \text { Authors' calculations using population census data }\end{array}$

to banks or to counties that have a local bank. We do this by controlling for immigration flows in each county from other states and from abroad. This is an imperfect measure of moving to finance but the census reports only state or country of birth.

Finally, we acknowledge the fact that the fertility behaviour of one county is likely to affect that of neighbouring counties. To address this, we control for spatial correlation by including a spatial component in the error term of our regressions. Table 1 displays the source of each variable while Table 2 shows some descriptive statistics. 
Table 2: Descriptive statistics

\begin{tabular}{lcccc}
\hline \hline & $(1)$ & $(2)$ & $(3)$ & $(4)$ \\
\hline & Mean & Std. dev. & Min & Max \\
\hline Child-woman ratio & 0.67 & 0.14 & 0.35 & 1.10 \\
Child-woman ratio 2 & 0.55 & 0.11 & 0.28 & 0.90 \\
Child-woman ratio 3 & 1.67 & 0.30 & 0.87 & 2.39 \\
Crude birth rate & 0.02 & 0.00 & 0.01 & 0.04 \\
Bank dummy 1830s (1836-39) & 0.68 & 0.47 & 0 & 1 \\
Bank dummy 1840s (1846-49) & 0.70 & 0.46 & 0 & 1 \\
Intensive banking 1830s (1836-39) & 41.03 & 57.26 & 0 & 339.12 \\
Intensive banking 1840s (1846-49) & 22.28 & 30.58 & 0 & 272.68 \\
Share of literate women (older than 20) & 0.93 & 0.07 & 0.63 & 0.99 \\
Share of literate men (older than 20) & 0.96 & 0.04 & 0.67 & 0.99 \\
Education gap (women/men) & 0.98 & 0.04 & 0.73 & 1.06 \\
School attendance & 0.68 & 0.13 & 0.40 & 1.01 \\
Proxy income per capita & 0.33 & 0.22 & 0.03 & 1.71 \\
Share in manufacturing & 0.08 & 0.07 & 0.00 & 0.39 \\
Share of urban population & 0.15 & 0.24 & 0 & 1 \\
Proxy share of married women & 0.62 & 0.05 & 0.46 & 0.88 \\
Marriage rate & 0.01 & 0.00 & 0.00 & 0.02 \\
Crude death rate & 0.01 & 0.00 & 0.00 & 0.06 \\
Agricultural productivity & 1.81 & 1.29 & 0.41 & 16.12 \\
Migration from other state & 0.11 & 0.08 & 0.00 & 0.50 \\
Migration from abroad & 0.11 & 0.09 & 0.00 & 0.47 \\
\hline \hline
\end{tabular}

Data on 196 U.S. counties belonging to New Hampshire, Vermont, Massachusetts, Rhode Island, Connecticut, New York, New Jersey, Pennsylvania and Delaware. 


\section{$5 \quad$ Empirical analysis}

\subsection{Empirical strategy}

Our empirical strategy consists of estimating several cross-sectional regressions of the following form:

$$
\text { fert }_{i}=\gamma_{1} \text { findev }_{i}+\gamma_{2} X_{i}+\epsilon_{i}
$$

where fert $_{i}$ is the measure of fertility in county $i$ in 1850, findev f $_{i}$ is a measure of financial development in county $i$ in the period 1846-1849, $X_{i}$ includes the county-level control variables discussed in the previous section measured in 1850, and $\epsilon_{i}$ is a standard error term.

To account for spatial correlation, we also estimate a spatial error model, that is a model that includes a spatial component in the error term: ${ }^{21}$

$$
\text { fert }_{i}=\gamma_{1} \text { findev }_{i}+\gamma_{2} X_{i}+\mu_{i} \quad \mu_{i}=\lambda W \mu_{i}+\epsilon_{i}
$$

where $\mathrm{W}$ is the spatial weight matrix and $\mathrm{W} \mu_{i}$ is the spatially lagged error term. ${ }^{22}$ The inclusion of a spatial component in the error term allows to capture spatial patterns related to omitted variables such as, for example, the diffusion of new cultural norms.

The previous regressions are estimated using county data for 8 Northeastern states. We also consider counties in Pennsylvania as a separate case study. Pennsylvania is a convenient state to test the old-age security hypothesis because its banking policy was slow to respond to changes in demand for banks. As a direct consequence of the Omnibus Banking Act passed

\footnotetext{
${ }^{21}$ Spatial error models are estimated by MLE using Stata command spmlreg (see Jeanty 2010).

${ }^{22}$ The inverse distance spatial weights matrix is computed using average latitude and longitude of each county.
} 
in 1814 in which the state was divided into twenty-seven districts, a total of forty-one banks were chartered and each district received at least one bank. Pennsylvania did charter banks after 1814, just not as many as other states and it tended to do so in clusters (Bodenhorn 2008). In fact, there was a second "wave" of charters in the 1830s. Since in this context it is indeed hard to argue that the effect of local banks on fertility reflects reverse causality, we take banks existing circa 1840-1850 as exogenous and we consider their association with fertility around 1850 .

\subsection{Results: cross-section}

Figure 2 shows the unconditional relationship between the bank dummy - a measure of banking's availability - and fertility across counties. It is apparent that there is a strong negative correlation between the two variables - as implied by the old-age security hypothesis - and this is not driven by outliers. The average (median) fertility level in counties that had at least one local bank was $0.62(0.59)$, whereas the figure for counties without banks were $0.79(0.78)$.

We now proceed to study this relationship more systematically. Table 3 reports the OLS estimates of equation (4) using the banking dummy as a proxy for the availability of financial markets. The coefficient on local bank development is significantly negative in all specifications, providing strong support for the hypothesis that financial development reduces the incentives of families to have a large offspring. The association of schooling with fertility is negative and significant in almost all specifications, suggesting that the quantity-quality trade-off played a role in shaping fertility choice (e.g. Galor and Weil 2000). Our first proxy of income per capita does not show a robust significant correlation. However, urbanization rates are negatively associated with fertility. Higher shares of employment in manufacturing are related to lower child-to-women ratios. It may be that industrial development reduces fer- 
tility by increasing the opportunity cost of childbearing for women since production becomes more skilled biased and women tend to have a comparative advantage in mental capacities vs. physical ones (Galor and Weil 1996). ${ }^{23}$ Men's literacy and the education gap (measured as the ratio of women's over men's literacy) display a negative correlation with fertility confirming the relevance of the gender gap in affecting fertility choice. As expected fertility is higher in counties with a larger share of married women, and agricultural productivity is negatively associated to fertility. As mentioned above, one potential concern with this regression is the possibility of selective migration: households who prefer finance to children as a technology to implement inter-temporal transfers or those with few or no children at all may, for some reason, relocate closer to banks. In order to address this we construct proxies for immigration flows to a given county from other U.S. states and from abroad. ${ }^{24}$ Immigration flows from other U.S. states tend to be negatively (but not significantly) associated with fertility, whereas immigration from abroad is positively related to fertility. The latter could reflect that immigrants may have preferences for larger families that are culturally rooted and that persist in a different environment. Importantly though, the coefficient associated with banking survives the inclusion of these migration controls. Finally all specifications include state dummies to capture common (state-level) characteristics.

Using the specification with the largest number of controls (8) our estimates suggest that the presence of a bank in a given county reduced the child-woman ratio approximately by 3 percentage points or from 0.67 to 0.64 children per woman. This reduction represents about one-fourth of the standard deviation in the child-woman ratio. It is interesting to note that the $R^{2}$ associated with our regressions is high, indicating that our empirical model captures a substantial share of cross-county variation in fertility.

In Table 4 we show the estimates of the same regressions but now using a measure of intensity

\footnotetext{
${ }^{23}$ For example, Wanamaker (2012) finds a negative correlation between industrialisation and fertility in 19th century South Carolina.

${ }^{24}$ Unfortunately, the census does not report migration at the county level.
} 


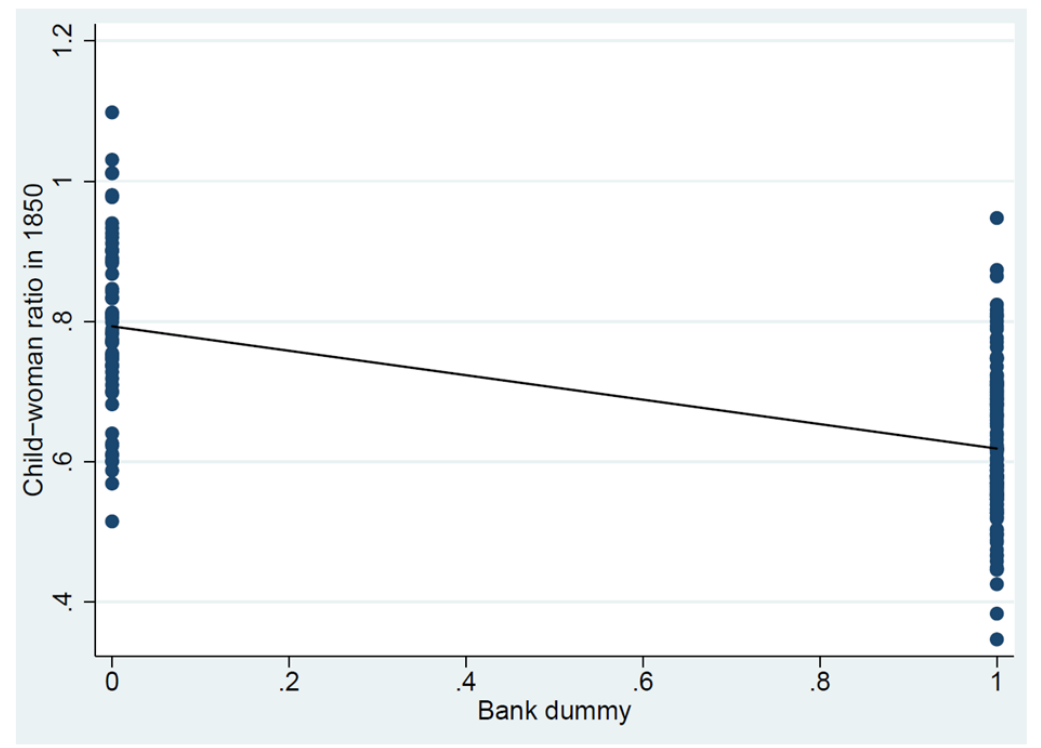

Figure 2: Child-woman ratio and bank dummy across counties

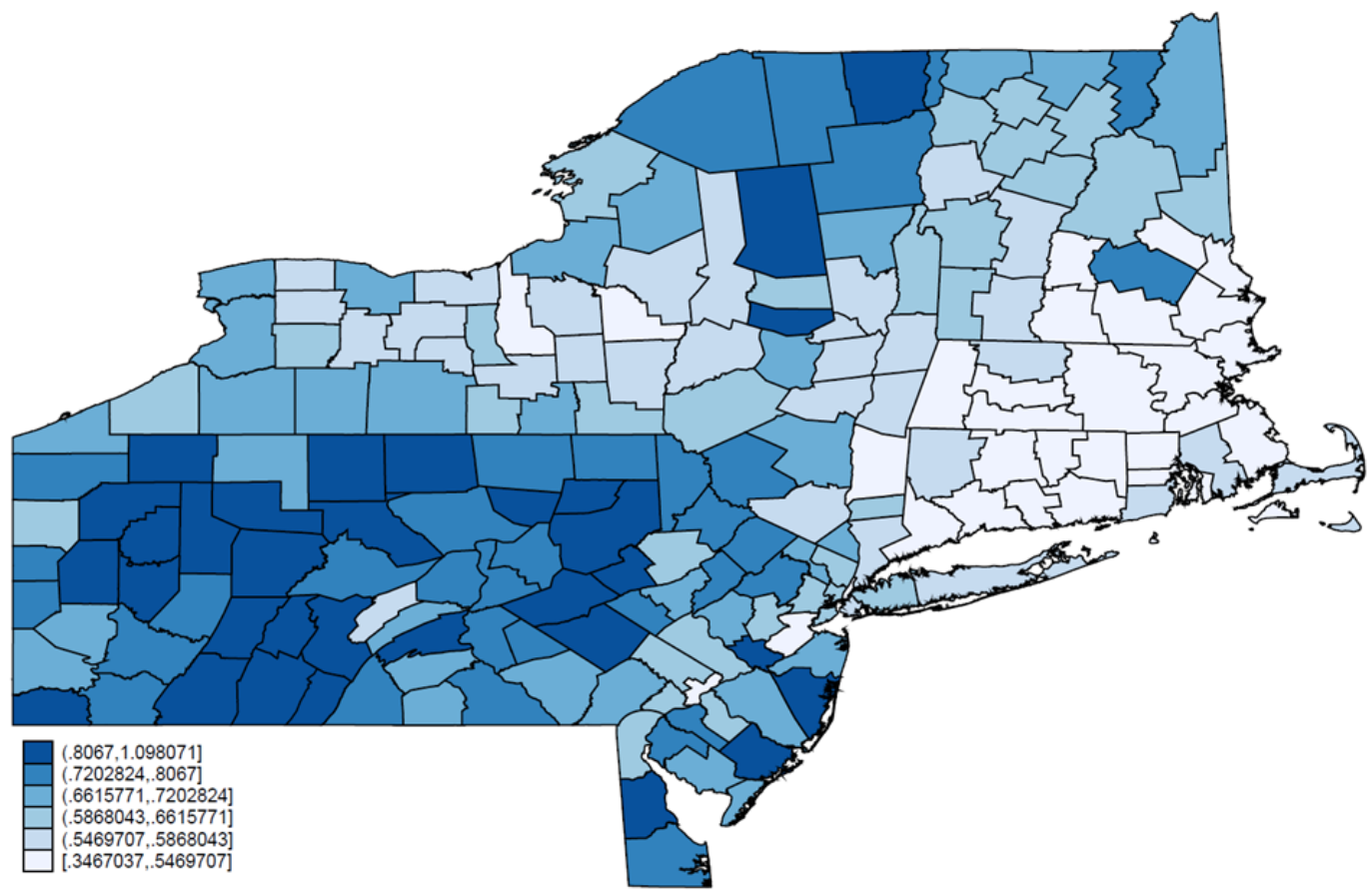

Figure 3: Child-woman ratios across counties in 1850 
- rather than simply the presence of at least a bank - of banking in each county. Similar to Table 3, counties with higher intensity of financial activity are characterized by lower fertility levels. A one standard deviation change in local bank money holdings is associated with a 3 percentage-point decrease in the child-woman ratio, based on estimates in Columns (6)-(8). This holds when controlling for all the previously discussed potential explanatory factors that determine fertility behaviour.

Figure 3 shows the spatial distribution of the child-woman ratio across the counties in our sample. A casual look at the map suggests the presence of possible spatial effects in fertility. In order to account for the potential role of spatial correlation, we estimate a spatial error model (Equation 5). We report two different regressions for the two measures of banking, availability and intensity: one including state dummies and one without them. Table 5 displays the estimates of this model. As in Tables 3 and 4 we find a strong and robust negative association between financial development and fertility. On the other hand there is evidence of spatial correlation (positive and significant $\lambda$ ) when we do not include the state dummies. Remarkably, when we include the state dummies the spatial component is not significantly different from zero, thus suggesting that spatial correlation is already captured by the state effects.

One potential issue that might affect our previous results is endogeneity. To partially tackle the potential bias of our OLS estimates we use Pennsylvania as a case study. Following up on our discussion in Section 5.1, studying the relationship between financial development and fertility in Pennsylvania is useful because in most of its counties banks were created before 1820 , so that it is hard to argue that their correlation with fertility reflects reverse causality. ${ }^{25}$ Table 6 shows that the coefficients on the bank dummy and banking intensity are still negative and statistically significant in this state, which is remarkable given the small number of observations (56 compared to 196 in the regressions that use the 8 states).

\footnotetext{
${ }^{25}$ We exclude 5 (out of 61 ) counties that got a bank after 1820 .
} 


\section{Robustness checks}

\subsection{Alternative measures of fertility}

Our first robustness check is to consider similar regressions to those previously estimated but using alternative child-to-women ratios, using children aged 1-4 (labelled CWR2) or 5-14 (labelled CWR3) and the crude birth rate (CBR) to measure fertility levels. ${ }^{26}$ Infant and child mortality may affect fertility through replacement of children that die; moreover, mortality risk can affect fertility through a precautionary demand for children (Tamura 1996, Kalemli-Ozcan 2002). By using children aged 1-4 or 5-14, CWR2 and CWR3 remove the potential effect of infant and/or child mortality, thus capturing surviving children. When we use the crude birth rate we control for the mortality environment (during childhood and also adulthood) by including as a control the (log) crude death rate. ${ }^{27}$ Since crude birth rates are defined as births over total population, we replace the family-to-woman ratio with the (log) marriage rate, calculated as the number of marriages (until June 1, 1850) over total population. When using the CWR3, the bank dummy and banking intensity are calculated using data on financial activities for the period 1836-39, so to be consistent with the new definition of the dependent variable. ${ }^{28}$ Table 7 shows that the results of this exercise are similar to those obtained in our previous regressions. Across all specifications our main variables of interest - the presence of at least a bank and the intensity of financial development show a significant negative relationship with fertility. School attendance and income per capita do not always display a negative association. Higher shares of employment in manufacturing are still related to lower child-to-women ratios. Urbanization is also negatively associated with fertility, as the education gap. Fertility is higher in counties with a larger share of married

\footnotetext{
${ }^{26} \mathrm{CWR} 3$ is computed using women aged $20-39$.

${ }^{27}$ Since surviving births are only measured between January and June, they only account for (initial) infant mortality but not for infant mortality six months after birth or child mortality.

${ }^{28}$ Children between 5 and 14 in 1850 were born between 1936-1945.
} 
women (or higher marriage rate), and agricultural productivity is negatively associated to fertility. Immigration flows to a given county from other U.S. states and from abroad tend to display a similar association as the one reported above, with some exceptions. ${ }^{29}$

Making similar calculations as in the previous section, our OLS estimates from column (3) suggest a drop in about $5 \%$ in crude birth rates, from an average of 0.25 to 0.24 (i.e. from 250 to 240 births per 1000 inhabitants).

\subsection{Panel}

Potential unobserved heterogeneity could affect our cross-sectional analysis. To investigate this possibility we collect data on banking intensity and fertility for the years 1840, 1850 and 1860 for counties not affected by changes in administrative borders. Using this (sub)set of counties we exploit the panel dimension to account for potential time-invariant omitted factors. We match child-to-women ratios (children aged 0-4 over women 15-39) in 1840 to financial activity in 1836-39, child-to-women ratios in 1850 to financial activity in 1846-49, and child-to-women ratios in 1860 to financial activity in 1856-59. Table 8 reports averages for the years in our sample while Table 9 displays the results of pooled (Columns 1-3) and fixed effects (Columns 4-6) OLS. We use three measures of financial development by disaggregating the general measure we used so far into two different indexes, one using only circulating currency and the other only deposits. The results suggest that levels of financial development are relevant in explaining levels of fertility (pooled OLS), while changes in banking might play a role - but not be the most important factor - in explaining changes in fertility (FE OLS), that is fertility transitions.

\footnotetext{
${ }^{29}$ Estimating spatial error models yield similar results. These tables are available from the authors upon request.
} 







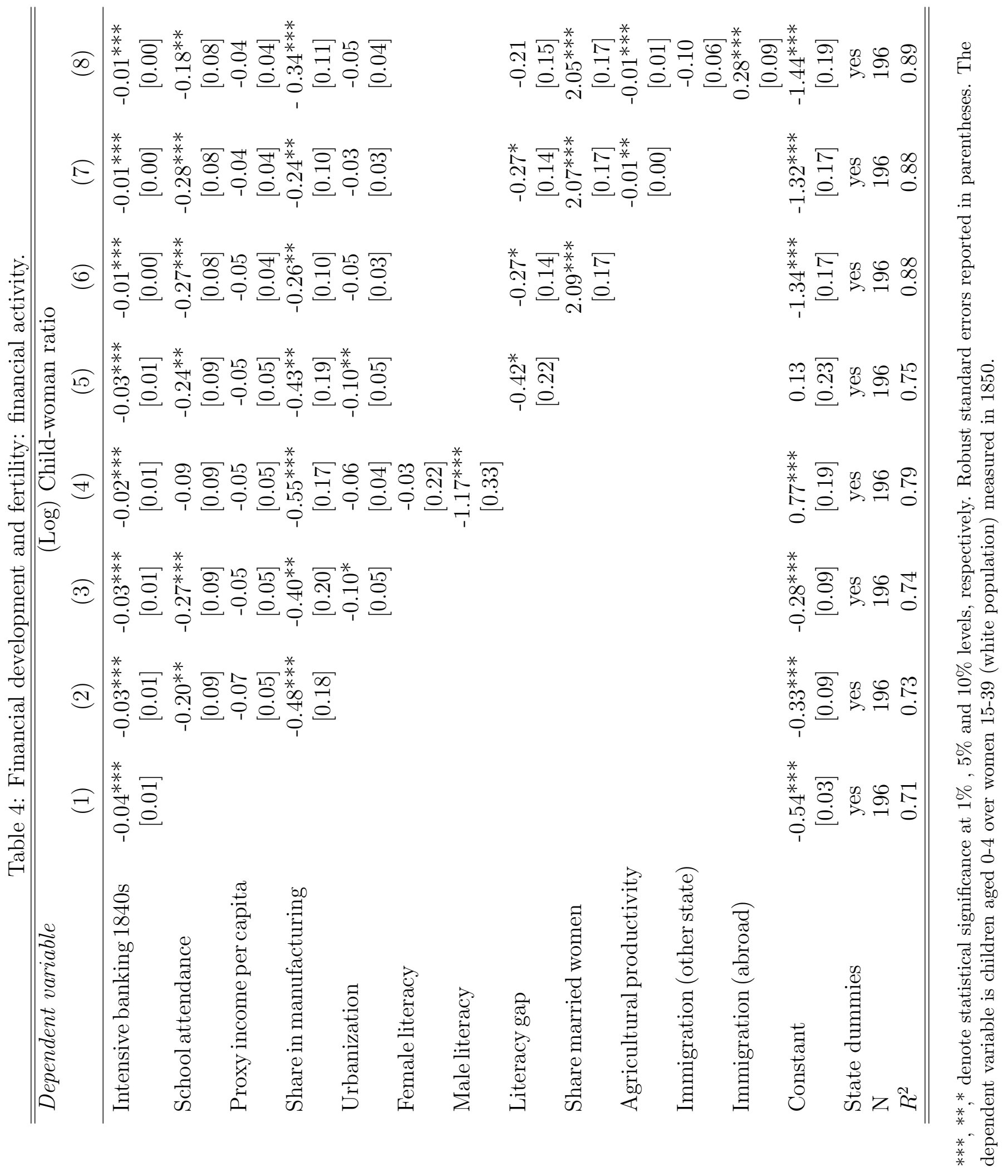


Table 5: Financial development and fertility: accounting for spatial correlation (MLE)

\begin{tabular}{lcccc}
\hline \hline Dependent variable & \multicolumn{5}{c}{ (Log) Child-woman ratio } \\
& $(1)$ & $(2)$ & $(3)$ & $(4)$ \\
\hline Bank dummy 1840s & $-0.04^{* * *}$ & $-0.07^{* * *}$ & & \\
& {$[0.01]$} & {$[0.02]$} & & \\
Intensive banking 1840s & & & $-0.01^{* * *}$ & $-0.02^{* * *}$ \\
& & & {$[0.00]$} & {$[0.01]$} \\
School attendance & $-0.17^{* *}$ & $-0.30^{* * *}$ & $-0.19^{* * *}$ & $-0.33^{* * *}$ \\
& {$[0.07]$} & {$[0.07]$} & {$[0.07]$} & {$[0.07]$} \\
Proxy income per capita & -0.05 & $0.07^{* *}$ & -0.04 & $0.09^{* * *}$ \\
& {$[0.04]$} & {$[0.03]$} & {$[0.04]$} & {$[0.03]$} \\
Share in manufacturing & $-0.32^{* * *}$ & $-0.47^{* * *}$ & $-0.32^{* * *}$ & $-0.48^{* * *}$ \\
& {$[0.10]$} & {$[0.12]$} & {$[0.10]$} & {$[0.12]$} \\
Urbanization & $-0.05^{*}$ & $-0.17^{* * *}$ & -0.05 & $-0.17^{* * *}$ \\
& {$[0.03]$} & {$[0.04]$} & {$[0.03]$} & {$[0.04]$} \\
Literacy gap & -0.20 & -0.25 & -0.21 & $-0.28^{*}$ \\
& {$[0.13]$} & {$[0.16]$} & {$[0.13]$} & {$[0.16]$} \\
Share married women & $2.09^{* * *}$ & $2.03^{* * *}$ & $2.05^{* * *}$ & $2.00^{* * *}$ \\
& {$[0.13]$} & {$[0.16]$} & {$[0.14]$} & {$[0.17]$} \\
Agricultural productivity & $-0.01^{* *}$ & -0.01 & $-0.01^{* *}$ & -0.00 \\
& {$[0.01]$} & {$[0.01]$} & {$[0.01]$} & {$[0.01]$} \\
Immigration (other state) & -0.08 & -0.05 & -0.08 & -0.04 \\
& {$[0.07]$} & {$[0.09]$} & {$[0.07]$} & {$[0.09]$} \\
Immigration (abroad) & $0.27^{* * *}$ & $0.36^{* * *}$ & $0.27^{* * *}$ & $0.36^{* * *}$ \\
& {$[0.09]$} & {$[0.10]$} & {$[0.09]$} & {$[0.10]$} \\
Constant & $-1.48^{* * *}$ & $-1.16^{* * *}$ & $-1.43^{* * *}$ & $-1.11^{* * *}$ \\
& {$[0.18]$} & {$[0.24]$} & {$[0.18]$} & {$[0.25]$} \\
$\lambda$ & 0.49 & $0.94^{* * *}$ & 0.49 & $0.94^{* * *}$ \\
State dummies & yes & no & yes & no \\
N & 196 & 196 & 196 & 196 \\
\hline \hline
\end{tabular}

$* * *, * *, *$ denote statistical significance at $1 \%, 5 \%$ and $10 \%$ levels, respectively. Standard errors reported in parentheses. The dependent variable is children aged 0-4 over women 15-39 (white population) measured in 1850. 
Table 6: Financial development and fertility: Pennsylvania case

\begin{tabular}{|c|c|c|c|c|}
\hline \multirow{3}{*}{ Dependent variable } & \multicolumn{4}{|c|}{ (Log) Child-woman ratio } \\
\hline & (1) & $(2)$ & (3) & (4) \\
\hline & OLS & OLS & OLS & OLS \\
\hline Bank dummy 1840s & $\begin{array}{c}-0.18^{* * *} \\
{[0.03]}\end{array}$ & $\begin{array}{c}-0.07^{* * *} \\
{[0.02]}\end{array}$ & & \\
\hline Intensive banking 1840s & & & $\begin{array}{c}-0.05^{* * *} \\
{[0.01]}\end{array}$ & $\begin{array}{c}-0.02^{* * *} \\
{[0.01]}\end{array}$ \\
\hline School attendance & & $\begin{array}{l}-0.16 \\
{[0.13]}\end{array}$ & & $\begin{array}{l}-0.17 \\
{[0.13]}\end{array}$ \\
\hline Proxy income per capita & & $\begin{array}{l}-0.08 \\
{[0.06]}\end{array}$ & & $\begin{array}{l}-0.08 \\
{[0.06]}\end{array}$ \\
\hline Share in manufacturing & & $\begin{array}{l}-0.10 \\
{[0.20]}\end{array}$ & & $\begin{array}{l}-0.08 \\
{[0.20]}\end{array}$ \\
\hline Urbanization & & $\begin{array}{c}0.07 \\
{[0.05]}\end{array}$ & & $\begin{array}{c}0.10^{* *} \\
{[0.05]}\end{array}$ \\
\hline Literacy gap & & $\begin{array}{l}-0.02 \\
{[0.16]}\end{array}$ & & $\begin{array}{l}-0.03 \\
{[0.16]}\end{array}$ \\
\hline Share married women & & $\begin{array}{c}2.77^{* * * *} \\
{[0.25]}\end{array}$ & & $\begin{array}{c}2.78^{* * *} \\
{[0.24]}\end{array}$ \\
\hline Agricultural productivity & & $\begin{array}{c}-0.03^{* *} \\
{[0.01]}\end{array}$ & & $\begin{array}{c}-0.03^{* *} \\
{[0.01]}\end{array}$ \\
\hline Immigration (other state) & & $\begin{array}{c}-0.24^{* * *} \\
{[0.08]}\end{array}$ & & $\begin{array}{c}-0.24^{* * * *} \\
{[0.07]}\end{array}$ \\
\hline Immigration (abroad) & & $\begin{array}{l}-0.13 \\
{[0.14]}\end{array}$ & & $\begin{array}{l}-0.14 \\
{[0.14]}\end{array}$ \\
\hline Constant & $\begin{array}{c}-0.17^{* * *} \\
{[0.02]}\end{array}$ & $\begin{array}{c}-1.75 * * * \\
{[0.27]}\end{array}$ & $\begin{array}{c}-0.16^{* * *} \\
{[0.02]}\end{array}$ & $\begin{array}{c}-1.74^{* * * *} \\
{[0.27]}\end{array}$ \\
\hline $\mathrm{N}$ & 56 & 56 & 56 & 56 \\
\hline$R^{2}$ & 0.40 & 0.88 & 0.42 & 0.88 \\
\hline
\end{tabular}

$* * *, * *, *$ denote statistical significance at $1 \%, 5 \%$ and $10 \%$ levels, respectively. Robust standard errors reported in parentheses. The dependent variable is children aged 0-4 over women 15-39 (white population) measured in 1850. Constant included in all regressions but not reported in the table. 


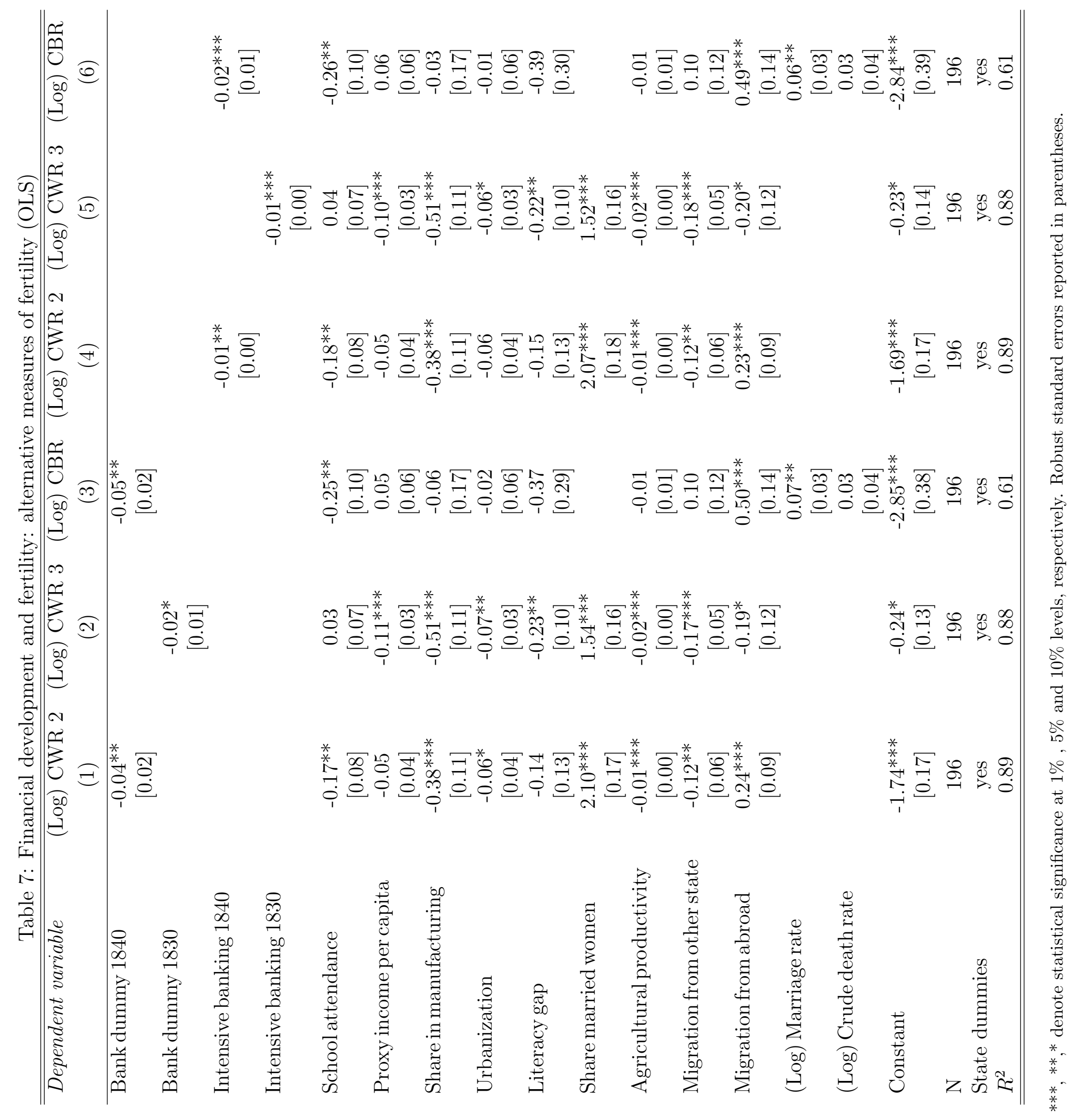


Table 8: Descriptive statistics: averages

\begin{tabular}{lccc}
\hline \hline Year & 1840 & 1850 & 1860 \\
\hline Child-woman ratio & 0.77 & 0.65 & 0.65 \\
$\begin{array}{l}\text { Financial development } \\
\text { (circulation+deposits, per capita) }\end{array}$ & 105.49 & 42.54 & 74.66 \\
$\begin{array}{l}\text { Financial development } \\
\text { (circulation, per capita) }\end{array}$ & 56.72 & 20.25 & 23.78 \\
$\begin{array}{l}\text { Financial development } \\
\text { (deposits, per capita) }\end{array}$ & 48.78 & 22.29 & 50.87 \\
\hline
\end{tabular}

Data on 98 U.S. counties not affected by changes in borders over the period 1830-1860.

Table 9: Panel (1840-1860). Pooled and fixed effects OLS

\begin{tabular}{|c|c|c|c|c|c|c|}
\hline \multirow[t]{2}{*}{ Dependent variable } & \multicolumn{6}{|c|}{ (Log) Child-woman ratio } \\
\hline & (1) & (2) & $(3)$ & $(4)$ & (5) & (6) \\
\hline $\begin{array}{l}\text { Intensive banking } \\
\text { (circulation+deposits) }\end{array}$ & $\begin{array}{c}-0.04^{* * *} \\
{[0.01]}\end{array}$ & & & $\begin{array}{l}-0.01^{*} \\
{[0.01]}\end{array}$ & & \\
\hline $\begin{array}{l}\text { Intensive banking } \\
\text { (circulation) }\end{array}$ & & $\begin{array}{c}-0.04^{* * *} \\
{[0.01]}\end{array}$ & & & $\begin{array}{l}-0.01 * \\
{[0.01]}\end{array}$ & \\
\hline $\begin{array}{l}\text { Intensive banking } \\
\text { (deposits) }\end{array}$ & & & $\begin{array}{c}-0.04^{* * *} \\
{[0.01]}\end{array}$ & & & $\begin{array}{c}-0.01^{*} \\
{[0.01]}\end{array}$ \\
\hline Constant & $\begin{array}{c}-0.16^{* * *} \\
{[0.03]}\end{array}$ & $\begin{array}{c}-0.16^{* * *} \\
{[0.03]}\end{array}$ & $\begin{array}{c}-0.18^{* * *} \\
{[0.03]}\end{array}$ & $\begin{array}{c}-0.25^{* * *} \\
{[0.02]}\end{array}$ & $\begin{array}{c}-0.25^{* * *} \\
{[0.02]}\end{array}$ & $\begin{array}{c}-0.25^{* * *} \\
{[0.01]}\end{array}$ \\
\hline Year 1850 & $\begin{array}{c}-0.19^{* * * *} \\
{[0.01]}\end{array}$ & $\begin{array}{c}-0.19^{* * * *} \\
{[0.01]}\end{array}$ & $\begin{array}{c}-0.19^{* * * *} \\
{[0.01]}\end{array}$ & $\begin{array}{c}-0.17^{* * *} \\
{[0.01]}\end{array}$ & $\begin{array}{c}-0.18^{* * *} \\
{[0.01]}\end{array}$ & $\begin{array}{c}-0.18^{* * * *} \\
{[0.01]}\end{array}$ \\
\hline Year 1860 & $\begin{array}{c}-0.17^{* * *} \\
{[0.01]}\end{array}$ & $\begin{array}{c}-0.18^{* * *} \\
{[0.01]}\end{array}$ & $\begin{array}{c}-0.16^{* * *} \\
{[0.01]}\end{array}$ & $\begin{array}{c}-0.17^{* * *} \\
{[0.01]}\end{array}$ & $\begin{array}{c}-0.17^{* * *} \\
{[0.01]}\end{array}$ & $\begin{array}{c}-0.17^{* * *} \\
{[0.01]}\end{array}$ \\
\hline Time dummies & yes & yes & yes & yes & yes & yes \\
\hline Fixed effects & no & no & no & yes & yes & yes \\
\hline Counties & 98 & 98 & 98 & 98 & 98 & 98 \\
\hline $\mathrm{N}$ & 294 & 294 & 294 & 294 & 294 & 294 \\
\hline
\end{tabular}

$* * *, * *, *$ denote statistical significance at $1 \%, 5 \%$ and $10 \%$ levels, respectively. Robust standard errors clustered at the county level reported in parentheses 


\section{Conclusions}

This paper empirically explores the relevance of the so-called old-age security hypothesis to explain differences in fertility levels. We find evidence that the availability and intensity of banking are related to lower fertility levels across Northeastern U.S. counties in the 19th century. Our results are robust to a number of socio-economic controls and the presence of spatial effects in the data. This finding provides strong support for the importance of the old-age security hypothesis, which argues that children are one of the instruments that parents use to secure support when old. A corollary of this theory - precisely what we test in this paper - is that the availability of alternative tools might then reduce the incentives of households to have a large offspring.

This finding has important policy implications for today's developing countries that still have relatively high fertility levels. Our results suggest that policies designed to provide access to banking services (or social security systems) may reduce parents' incentives to have a large number of children, thus facilitating increases in standard of livings via the well-known child quantity-quality trade-off. 


\section{References}

[1] Barro, R. and G.S. Becker (1989). "Fertility Choice in a Model of Economic Growth," Econometrica, 57 (2), pp. 481-501.

[2] Becker, G. S. (1981). A Treatise on the Family. Harvard University Press, Cambridge, MA.

[3] Becker, G. S. and Lewis, H. G. (1973). "On the Interaction between the Quantity and Quality of Children." Journal of Political Economics, 81, pp. 279-288.

[4] Becker, S. O., Cinnirella, F. and Woessmann, L. (2010). "The Trade-off between Fertility and Education: Evidence from Before the Demographic Transition," Journal of Economic Growth, 15(3), pp. 177-204

[5] Becker, S. O., Cinnirella, F. and Woessmann, L. (2012). "The effect of investment in children's education on fertility in 1816 Prussia," Cliometrica, 6, pp. 29-44.

[6] Becker, S. O., Cinnirella, F. and Woessmann, L. (2013). "Does women's education affect fertility? Evidence from pre-demographic transition Prussia," European Review of Economic History 17(1), pp. 24-44.

[7] Bodenhorn, H. (2008). "Free Banking and Bank Entry in Nineteenth Century New York," Financial History Review, 15 (2), pp. 175-201.

[8] Bodenhorn, H. and Cuberes, D. (2013). "Financial Development and City Growth: Evidence from Northeastern American Cities, 1790-1870," NBER Working Paper No. $1599 \%$

[9] Boldrin, M. and Jones, L. (2002). "Mortality, fertility, and saving in a Malthusian economy", Review of Economic Dynamics, 5, pp. 775-814. 
[10] Brown, J. C. and Guinnane, T. W. (2002). "Fertility Transition in a Rural, Catholic Population: Bavaria 1880-1910", Population Studies, 56 (1), pp. 35-49.

[11] Cain, M. (1977). "The Economic Activities of Children in a Village in Bangladesh," Population and Development Review 3, pp. 201-227.

[12] Cain, M. (1981). "Risk and Insurance: Perspectives on Fertility and Agrarian Change in India and Bangladesh," Population and Development Review 7 (1981), pp. 435-474.

[13] Caldwell, J.C. (1976). "Toward a restatement of demographic transition theory," Рориlation and Development Review, 2, pp. 321-366.

[14] Caldwell, J. C. (1982). Theory of Fertility Decline. London: Academic Press.

[15] Clark, G. and Hamilton, G. (2006). "Survival of the Richest: the Malthusian Mechanism in Pre-Industrial England," Journal of Economic History 66(3),pp. 707-736.

[16] Coale, A. J. (1973). "The Demographic Transition." in International Population Conference, 1, International Union for the Scientific Study of Population, Liege, pp. 53-72.

[17] Cochrane, S. (1979). Fertility and Education: What Do We Really Know?" Johns Hopkins Press, Baltimore.

[18] Dharmalingam, A. (1994). "Old Age Support: Expectations and Experiences in a South Indian Village," Population Studies 48, pp. 5-19.

[19] Ehrlich, I. and Lui, F. T. (1991). "Intergenerational Trade, Longevity, and Economic Growth." Journal of Political Economy, 99(5), pp. 1029-1059.

[20] Entwisle, B. and C. R. Winegarden (1984). "Fertility and Pension Programs in LDCs: A Model of Mutual Reinforcement." Economic Development and Cultural Change 32, pp. 331-354. 
[21] Galloway, P.R., Lee, R. D., and Hammel, E. A. (1994). "Fertility decline in Prussia 1875 to 1910: a pooled cross-section time series analysis." Population Studies, 48(1), pp. $135-158$.

[22] Galloway, P.R., Lee, R. D., and Hammel, E. A. (1998). "Urban versus Rural: Fertility Decline in the Cities and Rural Districts of Prussia, 1875 to 1910." European Journal of Population, 14, pp. 209-264

[23] Galor, O. (2012). "The Demographic Transition: Causes and Consequences," Cliometrica, 6(1), pp. 1-28.

[24] Galor, O. and Weil, D. N. (2000). "Population, Technology, and Growth: From Malthusian Stagnation to the Demographic Transition and Beyond," American Economic Review, 90(4), pp. 806-828.

[25] Galor, O. and Weil, D. N. (1996). "The Gender Gap, Fertility, and Growth," American Economic Review 86(3), pp. 374-387.

[26] Goldin, C. (1990). Understanding the Gender Gap: An Economic History of American Women. Oxford University Press, New York.

[27] Guinnane, T. W. (2011). "The Historical Fertility Transition and Theories of Long-Run Growth: A Guide for Economists," Journal of Economic Literature, 49(3), pp. 589-614.

[28] Guiso, L., Sapienza, L. and Zingales, L. (2004). "Does Local Financial Development Matter?", The Quarterly Journal of Economics, 119(3), pp. 929-969.

[29] Hannon, J.H. (1984). "The Generosity of Antebellum Poor Relief", Journal of Economic History, 44(3), pp. 810-821.

[30] Hindle, S. (2004). "On the Parish: The Micro-Politics of Poor Relief in Rural England c. 1550-1750", Clarendon Press, Oxford. 
[31] Jeanty, P. W. (2010). "SPMLREG: Stata module to estimate the spatial lag, the spatial error, the spatial durbin, and the general spatial models by maximum likelihood," Statistical Software Components S457135, Boston College Department of Economics.

[32] Jensen, E. R. (1990). "An Econometric Analysis of the Old-Age Security Motive for Childbearing," International Economic Review, 31, 953-968.

[33] Kagitcibasi, C. (1982). "Old Age Security Value of Children; Cross-National Socioeconomic Evidence," Journal of Cross-Cultural Psychology, 13, pp. 29-42.

[34] Kalemli-Ozcan, S. (2002). "Does the Mortality Decline Promote Economic Growth?," Journal of Economic Growth, 7, pp. 411-439.

[35] Kaplan, H. (1994). "Evolutionary and Wealth Flows Theories of Fertility: Empirical Tests and New Models, Population and Development Review, 20, pp. 753-791.

[36] Lagerlöf, N.-P. (2003). "Gender Equality and Long-Run Growth", Journal of Economic Growth, 8 (4), pp. 403-426.

[37] Morand, O. F. (1999). "Endogenous Fertility, Income Distribution, and Growth," Journal of Economic Growth, 4, pp. 331-349.

[38] Neher, A.P. (1971). "Peasants, procreation and pensions," American Economic Review 61, pp. 380-389.

[39] Nerlove, M., A. Razin, and E. Sadka (1986). "Some Welfare Theoretic Implications of Endogenous Fertility." International Economic Review 27, pp. 3-31.

[40] Nerlove, M., A. Razin, and E. Sadka (1987). Household and Economy: Welfare Economics and Endogenous Fertility. Boston: Academic Press.

[41] Nugent, J. B. (1985). "The old-age security motive for fertility", Population and Development Review, 11, pp. 75-98. 
[42] Nugent, J. B., and T. Gillapsy. (1983). "Old-age Pension and Fertility in Rural Areas of Less Developed Countries: Some Evidence from Mexico," Economic Development and Cultural Change 31, pp. 809-829.

[43] Pelling, M. and Smith, R. M. (1991). Life, death and the elderly: historical perspectives. Routledge, London.

[44] Ray, D. 1998. Development Economics. Princeton University Press.

[45] Robinson, W. C. (1986). "High Fertility as Risk Insurance." Population Studies, 40, pp. 289-298.

[46] Rosenzweig, M. R, and R. Evenson (1977). "Fertility, Schooling, and the Economic Contribution of Children of Rural India: An Econometric Analysis." Econometrica 45(5), pp. 1065-1079.

[47] Sah, R. K. (1991). "The Effects of Child Mortality Changes on Fertility Choice and Parental Welfare," Journal of Political Economy, 99 (3), pp. 582-606.

[48] Steckel, R.H. (1991). The Fertility Transition in the United States: Tests of Alternative Hypotheses. In Strategic Factors in Nineteenth Century American Economic History. Claudia Goldin and Hugh Rockoff (eds.)

[49] Sylla, R. (1998). "U.S. Securities Markets and the Banking System, 1790-1840," Federal Reserve Bank of St. Louis Review, May/June, vol 8. No 3, pp. 83-98.

[50] Tamura, R. (1996). "From Decay to Growth: A Demographic Transition to Economic Growth," Journal of Economic Dynamics and Control, 20, pp. 1237-1262.

[51] Tamura, R. (2006). "Human Capital and Economic Development," Journal of Development Economics, 79, pp. 26-72. 
[52] Temin, P. (1969). The Jacksonian Economy. New York: W.W. Norton and Company.

[53] Wanamaker, M.H. (2012). "Industrialization and Fertility in the Nineteenth Century: Evidence from South Carolina", The Journal of Economic History, 72, pp. 168-196.

[54] Weber, W. E. (2011). "Balance sheets for U.S. Antebellum State Banks," Research Department, Federal Reserve Bank of Minneapolis. (http://www.minneapolisfed.org/research/economists/wewproj.html).

[55] Willis, R. J. (1980). "The Old Age Security Hypothesis and Population Growth." In T. Burch, ed., Demographic Behavior: Interdisciplinary Perspectives on Decision Making (pp. 43-69). Boulder, CO: Westview Press. 